\title{
Rancang Bangun Aplikasi Status Gizi Bayi Berbasis Android
}

\author{
Ima Kurniastuti ${ }^{1}$, Ahmad Syafiq Kamil ${ }^{2}$ \\ ${ }^{1,2}$ Program Studi Sistem Informasi Fakultas Teknik Universitas Nahdlatul Ulama Surabaya \\ E-mail: ima.kurniastuti@unusa.ac.id
}

\begin{abstract}
In this study an Android-based Baby Nutrition Status Application was designed to make it easier for health workers to determine the nutritional status of infants. The process is done by utilizing Evolus Pencil and Android Studio. Evolus Pencil is used to design a Graphical User Interface (GUI) that allows researchers to design interfaces of application. Android Studio is used to build applications according to the interface design. Input of application are nutritional anthropometry include age, gender, weight, length of baby, and head circumference obtained through the measurement process. The output of the application is below normal, normal, and above normal according to the Baby Nutrition Status Measurement Standards from the Indonesian Ministry of Health. The application testing results showed 100\% according to the Baby Nutrition Status Measurement Standards from the Indonesian Ministry of Health. However, for the development of applications it is still necessary to develop a display that is too simple and the application can be equipped with a login menu to find out the baby's development regularly.
\end{abstract}

Keywords: Application of baby's nutrition status, Anthopometry, Android

\begin{abstract}
ABSTRAK
Pada penelitian ini dilakukan rancang bangun Aplikasi Status Gizi Bayi Berbasis Android yang memudahkan petugas kesehatan dalam menentukan status gizi bayi. Proses dilakukan dengan memanfaatkan Evolus Pencil dan Android Studio. Evolus Pencil digunakan untuk merancang Graphical User Interface (GUI) yang memudahkan peneliti dalam merancang interface aplikasi. Android Studio digunakan untuk membangun aplikasi sesuai rancangan interface. Input pada aplikasi adalah antropomentri gizi diantaranya usia, jenis kelamin, berat badan, panjang bayi, dan lingkar kepala yang diperoleh melalui proses pengukuran. Output dari aplikasi adalah dibawah normal, normal, dan diatas normal sesuai Standar Pengukuran Status Gizi Bayi dari Kementerian Kesehatan RI. Hasil pengujian aplikasi menunjukkan 100\% sesuai dengan Standar Pengukuran Status Gizi Bayi dari Kementerian Kesehatan RI. Namun untuk pengembangan aplikasi masih perlu dilakukan pengembangan yaitu tampilan yang terlalu sederhana dan aplikasi dapat dilengkapi menu login untuk mengetahui perkembangan bayi secara berkala.
\end{abstract}

Kata kunci: Aplikasi status gizi bayi, Antropometri, Android

\section{PENDAHULUAN}

Berdasarkan Databoks Katadata Indonesia, Pada tahun 2017 pengguna smartphone di Indonesia mencapai 371,4 juta pengguna atau $142 \%$ dari total populasi penduduk Indonesia sebanyak 262 juta jiwa [1]. Jumlah tersebut membuktikan bahwa rata-rata setiap penduduk memakai 1,4 smartphone karena satu orang dapat menggunakan 2-3 smartphone. Pengguna smartphone di Indonesia sebagian besar memanfaatkan smartphone untuk mengakses mobile application dibandingkan mobile website. Sebanyak $82 \%$ pengguna smartphone di Indonesia mengakses mobile application sedangkan sisanya masing-masing 9\% pengguna mengakses mobile website dan website melalui dekstop. Populasi pengguna smartphone yang mengakses mobile application mayoritas berasal dari usia produktif yaitu $75 \%$ dari usia 18-24 tahun dan 79\% dari usia 25-34 tahun [2]. Hasil survei membuktikan bahwa 
perkembangan teknologi informasi dalam teknologi mobile telah berkembang dengan pesat. Perkembangan teknologi tersebut mengakibatkan adanya perubahan dan perkembangan di segala bidang, salah satunya adalah bidang kesehatan.

Kesehatan bayi merupakan hal yang sangat penting bagi orang tua. Orang tua menganggap bayi adalah sebuah harapan. Oleh karena itu, orang tua terutama ibu selalu memantau kesehatan bayi setiap harinya. Selain itu, Pemerintah Indonesia juga mengadakan Pos Pelayanan Terpadu (Posyandu) yang dilakukan oleh tenaga kesehatan setiap bulan untuk memantau kesehatan bayi. Kesehatan bayi yang perlu dipantau adalah status gizi bayi. Status gizi adalah status kesehatan yang dihasilkan oleh keseimbangan antara kebutuhan dan masukan zat gizi [3].

Terdapat dua cara yang dilakukan untuk menentukan status gizi yaitu pengukuran secara langsung dan pengukuran secara tidak langsung [4]. Pengukuran secara langsung dapat dilakukan melalui pemeriksaan biokimia, klinis dan biofisik. Pengukuran secara tidak langsung dapat dilakukan melalui antropometri gizi. Pengukuran menggunakan antoropometri gizi merupakan cara penentuan status gizi bayi yang sering dilakukan. Antropometri berhubungan dengan berbagai macam pengukuran dimensi tubuh dan komposisi tubuh dari berbagai tingkat umur dan tingkat gizi. Ukuran tubuh yang dimaksud adalah berat badan, tinggi badan dan lingkar kepala. Keunggulan antropometri yaitu alat yang digunakan mudah didapatkan dan digunakan, pengukuran dapat dilakukan berulang-ulang dengan mudah dan objektif, biaya relatif murah, hasilnya mudah disimpulkan, dan secara ilmiah diakui keberadaannya [4].

Antropometri gizi merupakan salah satu pengukuran status gizi yang dilakukan dengan mengukur beberapa parameter yang diukur dari tubuh manusia. Parameter tersebut adalah umur, berat badan, tinggi badan (panjang bayi). Parameter umur sangat penting dalam penetuan status gizi. Kesalahan penentuan umur akan menyebabkan interpretasi status gizi menjadi salah. Parameter berat badan dapat digunakan untuk melihat laju pertumbuhan fisik maupun status gizi. Sedangkan parameter tinggi badan adalah keadaan yang membandingkan keadaan yang lalu dengan keadaan sekarang [4]. Standar antropometri penilaian status gizi anak merujuk pada Keputusan Menteri Kesehatan Republik Indonesia No:1995/MENKES/SK/XII/2010 [5]. Standar tersebut dapat ditunjukkan pada Gambar 1 dan Tabel 1.

\begin{tabular}{|c|c|c|c|c|}
\hline \multirow{2}{*}{ UMUR } & \multicolumn{2}{|c|}{ BERAT BADAN (dalam Kg) } & \multicolumn{2}{|c|}{ TINGGI BADAN (dalam $\mathrm{Cm}$ ) } \\
\hline & Ideal & $80 \%$ Ideal & Ideal & $80 \%$ ideal \\
\hline Saat Lahir & 3,40 & 2,70 & 50,50 & 40,40 \\
\hline 1 Bulan & 4,30 & 3,40 & 55,00 & 44,00 \\
\hline 2 Bulan & 5,00 & 4,00 & 58,00 & 46,40 \\
\hline 3 Bulan & 5,70 & 4,60 & 60,00 & 48,00 \\
\hline 4 Bulan & 6,30 & 5,00 & 60,50 & 48,40 \\
\hline 5 Bulan & 6,90 & 5,50 & 64,50 & 51,60 \\
\hline 6 Bulan & 7,40 & 5,90 & 66,00 & 52,80 \\
\hline 7 Bulan & 8,00 & 6,40 & 67,50 & 54,00 \\
\hline 8 Bulan & 8,40 & 6,70 & 69,00 & 55,20 \\
\hline 9 Bulan & 8,90 & 7,10 & 70,50 & 56,40 \\
\hline 10 Bulan & 9,30 & 7,40 & 72,00 & 57,60 \\
\hline 11 Bulan & 9,60 & 7,70 & 73,50 & 58,80 \\
\hline 12 Bulan & 9,90 & 7,90 & 74,50 & 59,60 \\
\hline 1 Tahun 3 Bulan & 10,60 & 8,50 & 78,00 & 62,40 \\
\hline 1 Tahun 6 Bulan & 11,30 & 9,00 & 81,50 & 65,20 \\
\hline 1 Tahun 9 Bulan & 11,90 & 9,50 & 84,50 & 67,60 \\
\hline 2 Tahun & 12,40 & 9,90 & 87,00 & 69,60 \\
\hline
\end{tabular}

Gambar 1. Standar berat badan dan panjang bayi berdasarkan umur bayi [5]

Tabel 1. Standar pengukuran lingkar kepala pada bayi [5]

\begin{tabular}{ccc}
\hline $\begin{array}{c}\text { Jenis } \\
\text { kelamin }\end{array}$ & $\begin{array}{c}\text { Usia } \\
\text { (bulan) }\end{array}$ & Ideal $(\mathrm{cm})$ \\
\hline & $0-3$ & $38-44$ \\
Laki-laki & $3-6$ & $41-47$ \\
& $6-24$ & $41+\left(0.5^{*}\right.$ usia- \\
& $0-3$ & $6)$ \\
Perempuan & $3-6$ & $40-42$ \\
& $6-24$ & $40+\left(0.5^{*}\right.$ usia- \\
& & $6)$ \\
\hline
\end{tabular}

Dalam praktiknya di sebuah posyandu, untuk melakukan pengukuran antropometri bayi diperlukan kemampuan mengingat tenaga kesehatan. Hal itu disebabkan untuk setiap umur bayi, standar berat badan dan panjang bayi berbeda-beda. Oleh karena itu, diperlukan sebuah aplikasi yang mampu meringankan dan mempercepat proses pengukuran antropometri bayi yaitu aplikasi status gizi bayi berbasis android. Dengan adanya aplikasi ini diharapkan dapat mempermudah petugas kesehatan dalam menentukan status gizi bayi. Dalam berbagai 
bidang telah banyak dikembangkan aplikasi android diantaranya melakukan pembuatan sistem informasi perkembangan balita berbasis android [6], melakukan perancangan aplikasi penjualan batik berbasis android [7] dan melakukan rancang bangun aplikasi pembelajaran budaya Indonesia untuk anak sekolah dasar berbasis android [8].

Sistem informasi perkembangan balita yang dikembangkan oleh Janto menyatakan bahwa sistem dapat digunakan sebagai salah satu media untuk mencari informasi mengenai kesehatan balita dan mencatat perkembangan balita [6]. Sholih merancang aplikasi penjualan batik berbasis android yang menunjukkan bahwa aplikasi dapat bermanfaat dalam membantu sistem penjualan di Batik Puspa Kencana [7]. Selain itu, Murtiwiyati menghasilkan sebuah aplikasi pembelajaran budaya Indonesia untuk anak Sekolah Dasar berbasis android yang mampu berjalan dengan sangat baik pada perangkat berbasis android [8]. Pada artikel ini dilakukan rancang bangun Aplikasi Status Gizi Bayi Berbasis Android yang memudahkan petugas kesehatan dalam menentukan status gizi bayi.

\section{METODE}

Dalam rancang bangun ini pendukung yang diperlukan diantaranya perangkat lunak berupa pencil dan android studio serta handphone dengan sistem operasi Android sebagai perangkat pengujian aplikasi. Metode penelitian ditunjukkan pada Gambar 2. Pada metode penelitian, tahap pertama yang dilakukan adalah studi literatur, tahapan pencarian referensi terkait permasalahan yang dilakukan. Referensi dapat berupa buku, jurnal dan sumber internet. Tahap kedua adalah pembuatan desain GUI (Graphical User Interface) memanfaatkan perangkat lunak Evolus pencil. Evolus pencil merupakan sebuah aplikasi open source untuk mendesain sebuah user interface dan tersedia untuk berbagai sistem operasi seperti Linux, Windows dan MacOS. Keunggulan dari Evolus pencil adalah mudah digunakan untuk membuat desain antarmuka, tersedia tool collection, mampu meng-eksport document dalam bentuk html, png, pdf dan lainlain serta antarmuka yang dihasilkan pun mudah dipahami oleh orang awam tanpa memerlukan tutorial [9].

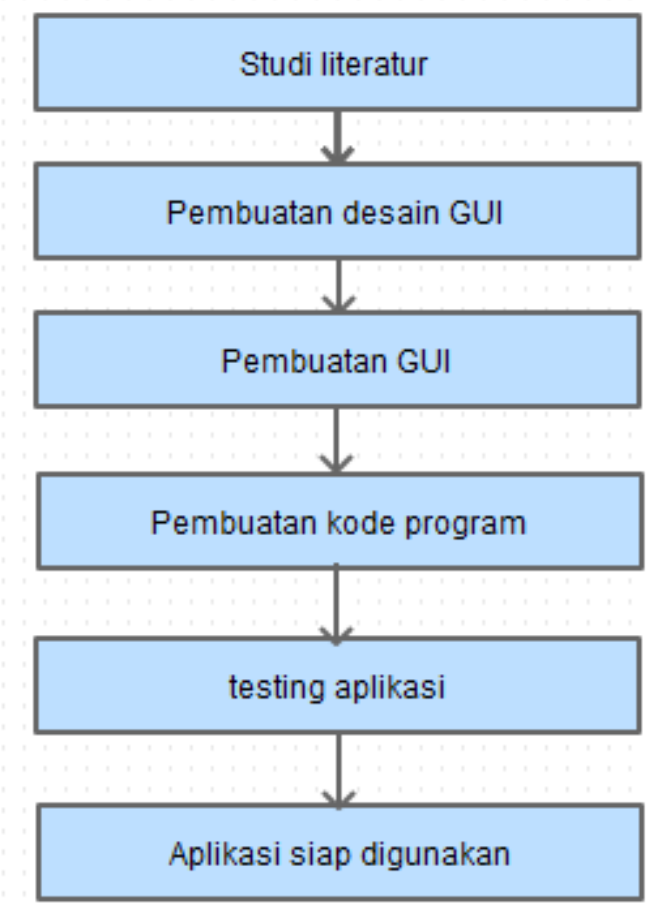

Gambar 2. Metode penelitian

Pada tahap ketiga yaitu pembuatan GUI dilakukan di Android Studio untuk menghasilkan tampilan aplikasi yang akan muncul pada saat pengguna mengoperasikan aplikasi. GUI aplikasi dibuat berdasarkan desain yang telah dibuat sebelumnya menggunakan perangkat lunak Evolus pencil. Untuk tahap ketiga dan keempat ini, perangkat lunak yang digunakan adalah Android studio, sebuah aplikasi open source yang menghasilkan aplikasi yang dapat dioperasikan pada perangkat keras yang menggunakan sistem operasi android.

Tahap selanjutnya adalah pembuatan kode program yang dilakukan pada lembar kerja yang disediakan pada android studio. Pengembangan menggunakan pedomana dari Sessa [10]. Bahasa pemrograman yang digunakan adalah bahasa pemrograman java. Tahap ini merupakan tahap penting dalam penelitian ini. Jika kode program 
mengalami kesalahan atau error maka aplikasi tidak berjalan sukses. Tahap terakhir dalam penelitian ini adalah pengujian aplikasi yaitu tahapan dimana aplikasi diuji pada handphone dengan sistem operasi android. Tahapan ini bertujuan untuk membuktikan apakah aplikasi berjalan dengan baik saat dijalankan di mobile device. Jika pengujian aplikasi berhasil maka aplikasi telah dapat digunakan.

\section{HASIL DAN PEMBAHASAN}

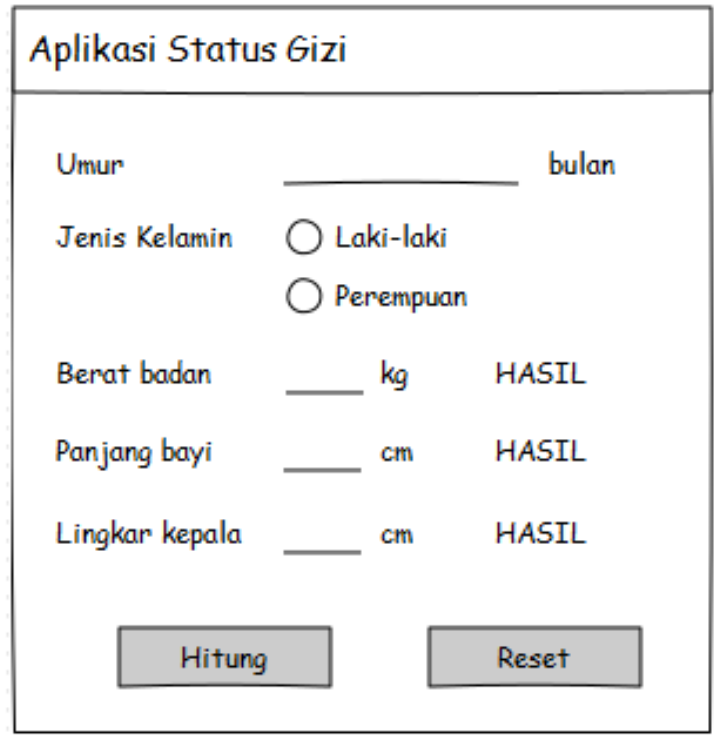

Gambar 3. Desain GUI aplikasi

Desain GUI aplikasi status gizi bayi yang memanfaatkan perangkat lunak evolus pencil ditunjukkan pada Gambar 3. Pada GUI terdapat beberapa fitur yang digunakan diantaranya adalah fitur TextView, fitur Radiogroup dan fitur Button. Pada fitur TextView digunakan sebagai inputan dari aplikasi. Disebabkan inputan dari aplikasi terdiri dari 4 (empat) buah yaitu usia, berat badan, panjang bayi dan lingkar kepala maka text yang digunakan dalam aplikasi ini sebanyak 4 (empat) buah pula. Fitur Radiogroup dimanfaatkan pada input jenis kelamin dimana pilihan jenis kelamin yang disediakan ada 2 (dua) buah yaitu laki-laki dan perempuan. Sedangkan fitur Button digunakan sebagai tanda untuk dimulainya sebuah proses yaitu proses hitung (pemeriksaan) dan proses reset. Tombol hitung berfungsi untuk memulai proses pemeriksaan berdasarkan Standar Pengukuran Status Gizi Bayi dari Kementerian Kesehatan Republik Indonesia. Sedangkan tombol reset merupakan tombol untuk menghapus semua input yang dilakukan oleh pengguna sebelumnya sehingga memudahkan pengguna dalam melakukan pemeriksaan status gizi bayi berikutnya. Untuk output, aplikasi memanfaatkan fitur TextView dimana TextView akan berubah menjadi hasil pemeriksaan ketika tombol hitung ditekan.

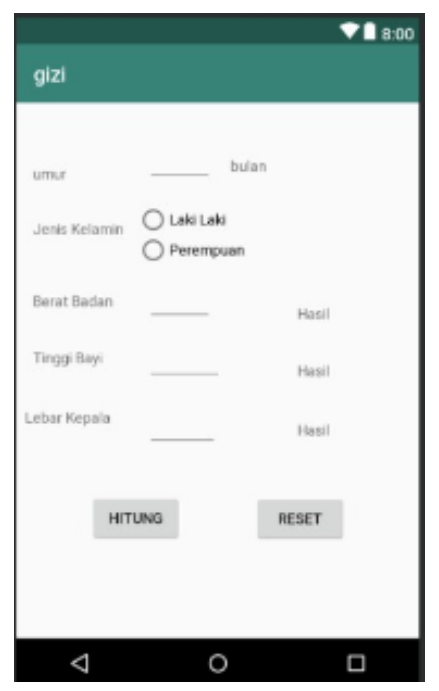

Gambar 4. Tampilan GUI aplikasi

Pada Gambar 4 menunjukkan tampilan GUI aplikasi pada android studio. Dalam pengoperasian aplikasi ini, pengguna diharuskan untuk memasukan input yang dibutuhkan dalam proses pemeriksaan yaitu usia, jenis kelamin, berat badan, panjang bayi dan lingkar kepala. Pada input usia, rentang usia yang disediakan dalam aplikasi ini adalah 0 (nol) hingga 24 (dua puluh empat) dengan satuan usia adalah bulan. Hal ini disebabkan pada Standar Pengukuran Status Gizi Bayi, usia yang dianggap sebagai bayi adalah bayi dengan rentang umur 0 (nol) hingga 24 (dua puluh empat) bulan. Input jenis kelamin dilakukan dengan memberikan pilihan kepada pengguna disebabkan adanya pilihan yang jelas dalam jenis kelamin yaitu laki-laki atau perempuan. Input berat badan dalam aplikasi ini diinput dalam satuan kilogram $(\mathrm{kg})$ 
sedangkan input panjang bayi dan lingkar kepala diinput dalam satuan centimeter $(\mathrm{cm})$.

Tahapan selanjutnya adalah pembuatan kode program. Kode program dibuat sesuai dengan tabel Standar Pengukuran Status Gizi Bayi sebelumnya. Cuplikan kode program pada android studio ditunjukkan pada Gambar 5. Proses selanjutnya dalam penelitian ini adalah proses pengujian. Proses pengujian dilakukan dalam dua cara yaitu cara pertama dilakukan pada laptop atau komputer dan cara kedua dilakukan di handphone. Cara pertama tidak disarankan karena memerlukan spesifikasi komputer yang tinggi yang berpengaruh dalam running time. Running time adalah waktu yang diperlukan oleh aplikasi dalam menjalankan kode program yang telah dibuat sebelumnya. Spesifikasi komputer yang paling berpengaruh adalah prosesor, kapasitas memori dan hardisk. Cara kedua lebih baik dilakukan dengan memanfaatkan handphone dengan Sistem Operasi Android disebabkan dapat mempersingkat running time. Namun pada cara kedua, pengaturan pada handphone harus diubah dalam bentuk mode developer sehingga handphone dapat tersambung langsung dengan Android studio. Pada penelitian ini, peneliti menggunakan cara kedua yaitu dengan menggunakan handphone dengan Sistem Operasi Android. Pada Gambar 6a menampilkan aplikasi yang terinstall di handphone, Gambar $6 \mathrm{~b}$ menampilkan aplikasi pada saat dibuka dan Gambar 6c menampilkan aplikasi pada saat pengujian.

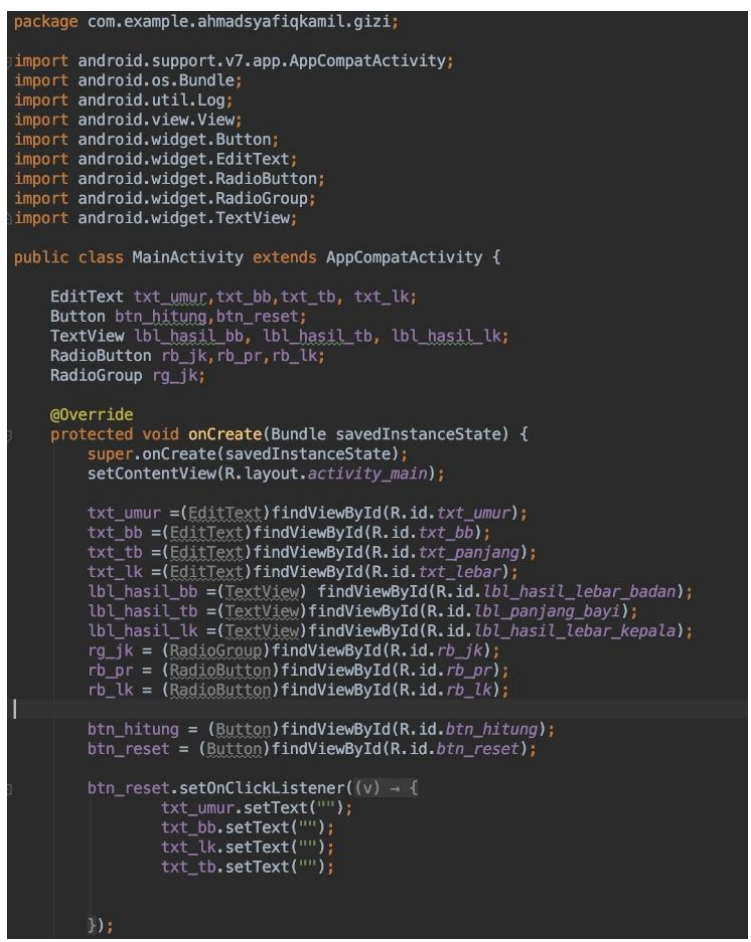

Gambar 5. Cuplikan kode program

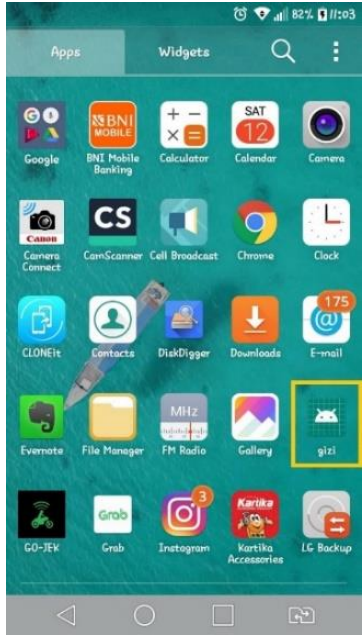

(a)
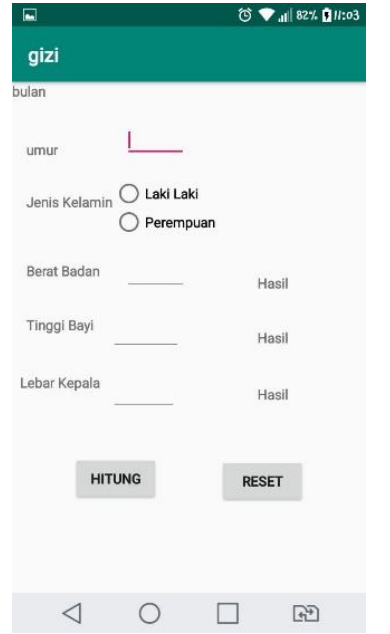

(b)

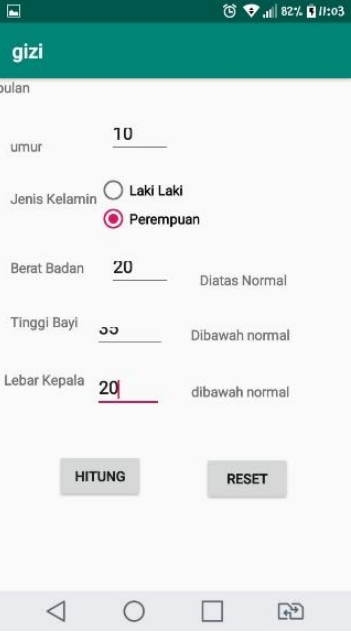

(c)

Gambar 6. (a) Tampilan aplikasi terinstall di handphone, (b) Tampilan aplikasi pada saat dibuka di handphone, (c) Tampilan aplikasi pada saat proses pengujian di handphone 
Pada Gambar 6c menampilkan aplikasi pada saat proses pengujian di handphone, dilakukan percobaan pengujian dengan input usia 10 bulan, jenis kelamin perempuan, berat badan $20 \mathrm{~kg}$, tinggi bayi $35 \mathrm{~cm}$ dan lingkar kepala $20 \mathrm{~cm}$ yang menghasilkan output berupa diatas normal untuk berat badan, dibawah normal untuk tinggi bayi dan dibawah normal untuk lingkar kepala. Output tersebut menunjukkan $100 \%$ sesuai dengan Standar Pengukuran Status Gizi Bayi yang dikeluarkan oleh Menteri Kesehatan Republik Indonesia [5]. Namun untuk pengembangan aplikasi, masih perlu dilakukan banyak pengembangan baik dalam hal tampilan yang terlalu sederhana, text tidak sesuai dengan desain tampilan saat proses coding, aplikasi dapat dilengkapi dengan menu login untuk mengetahui perkembangan bayi secara berkala.

\section{SIMPULAN}

Aplikasi status gizi bayi berbasis android telah selesai dilakukan dan dapat dioperasikan dengan baik pada saat pengujian di handphone dengan Sistem Operasi Android. Dengan adanya aplikasi tersebut dapat mempermudah petugas kesehatan dalam menentukan status gizi bayi dan perlu dilakukan pengembangan lebih lanjut diantaranya penambahan menu berupa menu login untuk mengetahui perkembangan bayi secara berkala dan pengembangan dalam hal tampilan aplikasi.

\section{DAFTAR PUSTAKA}

[1] Katadata, "Pengguna Ponsel Indonesia Mencapai 142\% dari Populasi," Databoks, 2017. [Online]. Available:

https://databoks.katadata.co.id/datapublish/2017/ 08/29/pengguna-ponsel-indonesia-mencapai142-dari-populasi.

[2] D. Cahyo, "Penggunaan Smartphone di Indonesia Tahun 2017," Dewina Journal, 2017. [Online]. Available: http://dewinajournal.foutap.com/penggunaan-smartphone-diindonesia-tahun-2017/.

[3] S. IP, A. D.I, W. A, and A. E, "The Relationship of Giving Exclusive Breastfeeding to Nutritional Status of 0-6 Months Infants in Rajabasa Bandar Lampung Health Center Area," Major. (Medical J. Lampung Univ., vol. 3, no. 2, pp. 100-107, 2014.

[4] Supariasa, Penilaian Status Gizi. Jakarta.: EGC, 2001.

[5] D. B. Gizi, "Keputusan Menteri Kesehatan Republik Indonesia Nomor: 1995/MENKES/SK/XII/2010 Tentang Standar ANtropometri Penilaian Status Gizi Anak." Kementerian Kesehatan RI, 2011.

[6] D. Janto, "Sistem Informasi Perkembangan Balita Berbasis Android," Universitas Negeri Semarang, Semarang, 2016.

[7] F. B. Sholih, "Perancangan Aplikasi Penjualan Batik Berbasis Android (Studi Kasus di Batik Puspa Kencana, Laweyan, Solo)," Universitas Muhammadiyah Surakarta, 2014.

[8] Murtiwiyati and G. Lauren, "Rancang Bangun Aplikasi Pembelajaran Budaya Indonesia Untuk Anak Sekolah Dasar Berbasis Android," J. Ilm. Komputasi, vol. 12, no. 2, pp. 1-10, 2013.

[9] Evolus, "Top features of Pencil," Pencil Project. [Online]. Available: https://pencil.evolus.vn/Features.html.

[10]C. Sessa, 50 Android Hacks. Shelter Island, NY: Manning Publications, 2013. 